\title{
光色と誘蛾萃との關係に就いての杉山章本 氏の研究を紹介し、併せてその應用に及ぶ
}

正會員關 重 廣

(東京電氣株式會社)

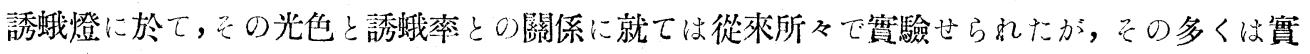
驗方法に不倩な點があって信賴しにくかったのであるが，今回農學士杉山章平氏か東大農學部 に於て貫驗された結果によつてこの多年の疑間がはつきりしたことは學界のために喜淡しい。

この䨘驗結果纹應用動物學雜誌昭和12年12月號に發表されてあるが，小生は多年誘蛾登に關 心持つて居つた一人であるため,こつにその大要を御紹介し，併せてその應用につき感想を 記したいと思ふ。

\section{硎究論文の大要}

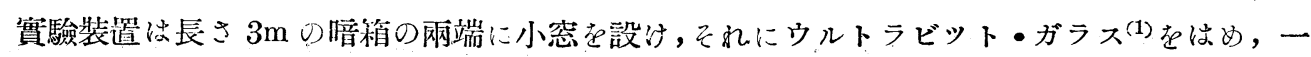
方の空は普通電球を以て外ょり照し，(これを白色光とする）他の空には色滤光板を當て，それ をバイタライトランプで照した。沿バイタライトの光は厚さ $10 \mathrm{~cm}$ の水層寺透して滤光板に當 てた。

實驗はこの箱の中央て數十匹の蛾を順をに放ちその蛾が白色光と色光とに分れて行く夫ぬ の數芭調べたのである。

色光を得るための滤光板は Wratten の10種を選んだ.

而して各滤光板に依る各色光の效果支比較するには，夫々白色光とその效果を比較して間接 的に求めたのであるが，その白色光と色光との效果走比較するに虫, 白色光の方の密の照度を 變へて數回の貫驗支行ひ，双方の密へ同數の蛾の行く場合の白色光の照度を求めた。そしてこ の白色光の照度の高低寺以って，その時の色光の刺激效果を表はするすの々考へたのである.

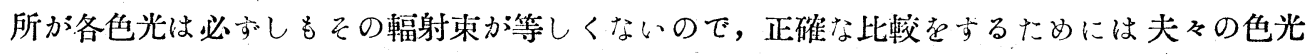
の輻射束て割らなければならない。をこで光源の各波長の輻射束をウャーンの式から求め,て れにバイタライトガラス，水，ウルトラビツト・ガラス，滤光板の夫々波長の透過率支乘じて， 殸に當る色光の輻射束を得てこれで前に得た結果の數値を割つた。かくして得た最後の數値 は次表の如くである。

此結果に低て，二化䗰䟤仙波長の短か心程䖯光反應力强く，特に $400 \mathrm{~m} \mu$ 上り短かい波長には 著しく强い。また赤色から赤外線に加けては㱠んそ反應を示さない。

以上は本實驗を小生か簡拔して紹介したので,實驗の全部ではないがとにかくこれによって 光色と誘蛾率との關係が制明したことは喜ばしいこそ〉思子。

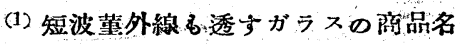




\begin{tabular}{|c|c|c|c|c|c|}
\hline $\begin{array}{l}\text { W ratten 瀘光 } \\
\text { 板の番號 }\end{array}$ & 光 & 色 & $\begin{array}{c}\text { 透過波長の籁圍 } \\
\text { mu. }\end{array}$ & 最大透過波長 $\mathrm{m} \mu$ & $\begin{array}{l}\text { 等輻射束の場合の } \\
\text { 䅟蛾 } 0 \text { 割 }\end{array}$ \\
\hline 18 & & & $330-400$ & 380 & 111.3 \\
\hline $1 \times 36$ & & & $360-460$ & 410 & 39.2 \\
\hline 49 & & & $360-510$ & 460 & 6.7 \\
\hline 75 & 毒 & 綠 & $450-540$ & 490 & 3.7 \\
\hline 74 & & & $510-570$ & 530 & 4.9 \\
\hline 73 & 簧 & 綠 & $55 J-630$ & 570 & 2.8 \\
\hline 72 & 橙 & 琵 & $580-660$ & 610 & 1.3 \\
\hline 71 & 橙 & 赤 & $600-680$ & 640 & 0.10 \\
\hline 70 & & & $640-700$ & 700 & 0.01 \\
\hline
\end{tabular}

\section{從來の實驗との比較}

從來行はれた二,三の實驗で，その不供な點老拾つてるると次のやうである。

(1) 同ワットの色電球を使用して比較した。

この方法は消費電力か同一でも, 色硝子によつて吸收の程度が違ひ, 輻射束が違ふから光色 の比較にはならない。この實驗の結果はいつも白色光即ち普通の電球のまつで色硝子を使はな いるのが番效果が强いことになり，次で黄，綠，青等の順になるがこれは當然である。つ まりこの順は輻射束の順になるのである。

然しこの實驗は嚴密な色光の比較にはならなくとも，實際に如何なる電球か一番效くかと云 ふ問題を解決する。この結果から普通の電球を一般に使用して居るのは正しい。

（2）輻射束の代りに照度を用ひた。即方同じ照度の色光で比較した。

これは同ワットで比较するより幾分よいやうに思はれるも，未だ不充分である・特に今回の 杉山氏の結果から判斷しても，人間の眼を基にした照度を基準にすることの危險が感ぜられる。 照度を用ひる方法:ホワット等しくらる方法のやうに實際的な參考にもならないまた嚴密な 色光比䡴にもならす，中途本端なものである。

（3）二つの光源への誘蛾數の比を以て直ちに二光線の效果の比較とした。

これはょくやる方法であるが嚴密に考へると面白くない.杉山氏の如く, 誘蛾の數が同一で 尚る場合の明るさり比起求めた方がよい。

大體以上のやうな色々の不借な點があつたのが，杉山氏の實驗ではこれらの點を洎重に取扱 つて適當な處理をされてある。

小生は從來から生物に對して法人間の腿を基とした照度などに囚はれず, 波長と輻射束とで 押へて實驗しなければな弓ないと主㖘して來た者であり，曾て松山市に於て，高岡慎吉氏と電 照養䖯の實驗をやつた際も，大山式輻射計を以て輻射束を測定し，等しい輻射束になるやうに

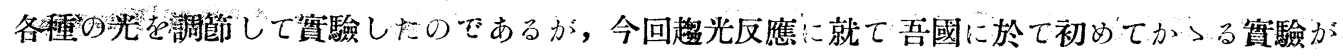
行はれたことは頗る愉快に思心(こつに一寸御斷はりしておくことは, 誘蛾燈, 或は點燈栽培 
などに於て，點燈の大體の標準を定めるために一番便利な方法として照度を用ひることに反對 するのではない。唯根本的な實驗をするのに照度を用ひてはあぶないと云ふまでら゙ある。）

\section{本實驗の結果を實際への應用}

本實驗は光色と二化蚯蛾の反應との關係を明らかにしたものであるが，これを實際に應用す るには經濟關係を考へなければならない，垻際問題としては從來行はれた實驗結果から，普通 の電球がよい事か制うて居るがもし特に短波を强く出す電燈があれば何よいことが考へられ る・水銀燈は一つの候補者であるが，從來のものは形が大きくて不便である・一番有然なるの

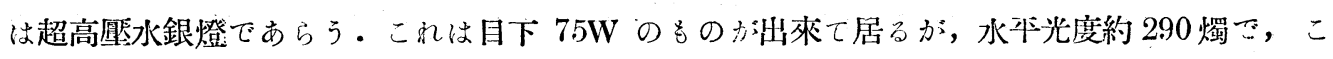

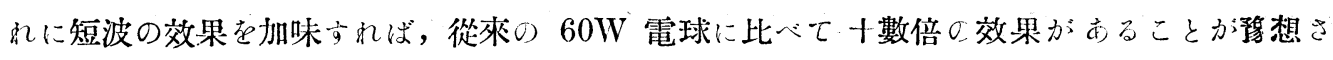

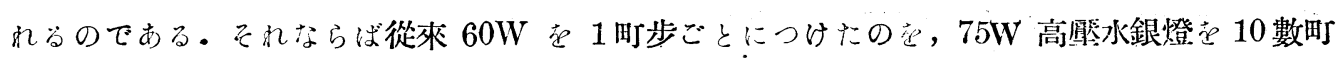
步に 1 燈の割でよいと云ふことになる。この場合逆自乘の法則は當はまるが，その代り面積と 距離 とが矢張り自乘關係になって，結局N倍明るい光は $\mathrm{N}$ 倍の相似形の面積夿同一の最低照度 で照し得ることになる。

かうなればたとへ電球の值段が高くとも, 電柱, 配線この他の設置費, 點燈料等の節約を考 へれば, 從來より結局安くなり, 誘蛾燈の經濟問題解決の一助ともなるのではあるまいか。

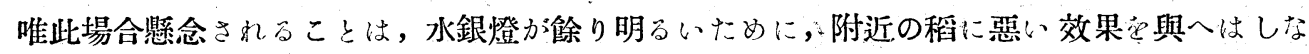
いかと云ふことと，いくら明るくともそれに此例して遠くきできくかそうかの二點である。特

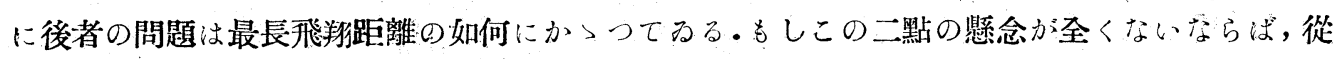
來とても普通の電球でも $60 \mathrm{~W} 1$ 町步の代りに, $200 \mathrm{~W}$, 㞔 4 町步 1 燈にしてもよい筈であ る.夫故かりにこの二點の䚋念があつても，水銀燈による短波の著し心效果がこれを打消して より以上に有利であればよいことになるのである。問題はこつに賏つて居ると思ふ。

(以上) 